\title{
PENGUATAN ECOLOGICAL CITIZENSHIP SEBAGAI UPAYA MENGUBAH PERILAKU MASYARAKAT SADAR AKAN LINGKUNGAN MELALUI PROGRAM KAMPUNG SELO BERAKSI
}

Oleh :

\author{
Hesti Fatmalasari, Erna Yuliandari, Dewi Gunawati \\ Program Studi PPKn FKIP Universitas Sebelas Maret Surakarta \\ e-mail: hestifatmalasari@gmail.com
}

\begin{abstract}
This study aims to find out: (1) Strengthening ecological citizenship in changing the behavior of people aware of the environment through the Kampung Selo Beraksi program; (2) Obstacles faced in realizing the Kampung Selo Beraksi program. This study uses qualitative research methods and descriptive research approaches. The research technique used was purposive sampling. Data collection uses interviews, observation and document analysis. Testing data validity using data triangulation and methods. Data analysis uses an interactive analysis model which includes: data reduction, data presentation, and conclusion drawing. Stages of research include: (1) Preparation; (2) Data collection; (3) Analysis of data; (4) Preparation of research reports.

The results of this study include: (1) Strengthening ecological citizenship is needed to arouse community awareness through environmental activities, namely the Kampung Selo Beraksi program. Insightful activities in the Kampung Selo Beraksi program include garbage banks, hydroponic parks, vertical gardens, craft galleries, and outbound. Strengthening ecological citizenship in the Kampung Selo Beraksi program is a bottom up approach that is realized through the formation of environmental knowledge, environmental skills, environmental attitudes, environmental participation. (2) The obstacles faced in realizing the Kampung Selo Beraksi program come from internal and external. The barriers to the Kampung Selo Beraksi program originating from the internal include: a) limited human resources due to lack of activeness and participation of the Kampung Selo community members; b) limited sources of funds in the development of the Kampung Selo Beraksi program. Barriers to the Kampung Selo Beraksi program originating from the external include: a) obstacles from the community, namely the existence of counter-attitudes from the community and a lack of community participation; b) obstacles from the government, namely lack of attention and participation of the local government; c) obstacles from the environment, namely the location of Kampung Selo Beraksi far from the city and the maximum arrangement of the village.
\end{abstract}

Keywords: Strengthening, ecological citizenship, Kampung Selo 


\begin{abstract}
ABSTRAK
Penelitian ini bertujuan untuk mengetahui: (1) Penguatan ecological citizenship dalam mengubah perilaku masyarakat sadar akan lingkungan melalui program Kampung Selo Beraksi; (2) Hambatan yang dihadapi dalam mewujudkan program Kampung Selo Beraksi. Penelitian ini menggunakan metode penelitian kualitatif dan pendekatan penelitian deskriptif. Teknik penelitian yang digunakan adalah purposivesampling. Pengumpulan data menggunakan wawancara, observasi dan analisis dokumen. Pengujian validitas data menggunakan triangulasi data dan metode. Analisis data menggunakan model analisis interaktif yang meliputi: reduksi data, sajian data, dan penarikan kesimpulan. Tahapan penelitian meliputi: (1) Persiapan; (2) Pengumpulan data; (3) Analisis data; (4) Penyusunan laporan penelitian.

Hasil dari penelitian ini meliputi: (1) Penguatan ecological citizenship diperlukan untuk menggugah kepedulian lingkungan masyarakat melalui kegiatan berwawasan lingkungan yaitu program Kampung Selo Beraksi. Kegiatan berwawasan dalam program Kampung Selo Beraksi diantaranya bank sampah, taman hidroponik, vertical garden, galeri kerajinan, dan outbound. Penguatan ecological citizenship dalam program Kampung Selo Beraksi merupakan pendekatan dari bawah (bottom up) yang diwujudkan melalui pembentukan environmental knowledge, environmental skills, environmental attitudes, environmental participation. (2) Hambatan yang dihadapi dalam mewujudkan program Kampung Selo Beraksi berasal dari internal dan eksternal. Hambatan program Kampung Selo Beraksi yang berasal dari internal meliputi: a) keterbatasan sumber daya manusia karena kurangnya keaktifan serta partisipasi anggota paguyuban Kampung Selo; b) keterbatasan sumber dana dalam pengembangan program Kampung Selo Beraksi. Hambatan program Kampung Selo Beraksi yang berasal dari eksternal meliputi: a) hambatan dari masyarakat yaitu adanya sikap kontra dari masyarakat dan kurangnya pastisipasi masyarakat; b) hambatan dari pemerintah yaitu kurangnya perhatian dan partisipasi pemerintah setempat; c) hambatan dari lingkungan yaitu letak Kampung Selo Beraksi yang jauh dari kota dan belum maksimalnya penataan kampung.
\end{abstract}

Kata kunci: Penguatan, ecological citizenship, Kampung Selo Beraksi 


\section{PENDAHULUAN}

Lingkungan sebagai tempat bagi manusia dan makhluk hidup lainnya untuk hidup dan berkembang biak, mencukupi kebutuhan seharisehari seperti oksigen, makanan, papan, dan kebutuhan lainnya yang dihasilkan dari alam. Sebagai satu kesatuan tempat, makhluk, kondisi, dan benda pada suatu ruang di mana manusia terikat di dalamnya maka lingkungan sangat berpengaruh terhadap kelangsungan hidup manusia. Negara Indonesia mengakui sepenuhnya bahwa lingkungan hidup merupakan karunia dari Tuhan untuk seluruh bangsa Indonesia secara keseluruhan dan tanpa pengecualian. Indonesia mengakui bahwa lingkungan hidup yang baik dan sehat sebagai salah satu kebutuhan dasar manusia sehingga dipandang perlu adanya perlindungan dan pengelolaan lingkungan hidup yang terencana sebagai salah satu aspek dalam pembangunan yang berkelanjutan. Undang-Undang Republik Indonesia, Nomor 32 Tahun 2009 tentang Perlindungan dan Pengelolaan Lingkungan Hidup, menjelaskan mengenai konsep lingkungan hidup sebagai berikut:

"Lingkungan hidup adalah kesatuan ruang dengan semua benda, daya, keadaan, dan makhluk hidup, termasuk manusia dan perilakunya, yang mempengaruhi alam itu sendiri, kelangsungan perikehidupan, dan kesejahteraan manusia serta makhluk hidup lain".

Landasan hukum terkait hak atas lingkungan yang baik dan sehat, antara lain: 1. Pasal $28 \mathrm{H}$ ayat (1) Undang-Undang Dasar 1945 bahwa "Setiap orang berhak hidup sejahtera lahir dan batin, bertempat tinggal, dan mendapatkan lingkungan hidup yang baik dan sehat serta berhak memperoleh pelayanan kesehatan." 2 . UU Nomor 39 Tahun 1999 tentang Hak Asasi Manusia yang berbunyi: "Setiap orang berhak atas lingkungan hidup yang bak dan sehat". 3. UU Nomor 32 Tahun 2009 Tentang Perlindungan Dan Pengelolaan Lingkungan Hidup Pasal 3 (b) Perlindungan dan pengelolaan lingkungan hidup bertujuan "Menjamin keselamatan, kesehatan dan kehidupan manusia". dan juga pada Pasal 3 (g) "Menjamin pemenuhan dan perlindungan hak atas lingkungan hidup sebagai bagian dari hak asasi manusia". Manusia hidup di lingkungan yang sama dengan orang lain sebagai sesama warga negara sehingga menimbulkan konsekuensi adanya kewajiban dan tanggung jawab untuk saling menjaga kelestarian lingkungan. Anugerah yang ada pada alam sebagai kekayaan milik bersama harus kita jaga sebaikbaiknya sehingga dapat dimanfaatkan untuk kehidupan pada masa sekarang maupun kehidupan generasi selanjutnya di masa mendatang.

Kehidupan manusia sangat bergantung keadaan lingkungan. Lingkungan sebagai komponen yang sangat mempengaruhi kehidupan manusia, mempunyai kemampuan untuk mendukung kehidupan manusia yang harus dijaga. Kerusakan lingkungan dapat disebabkan oleh dua faktor yaitu faktor dari dalam dan dari luar. Kerusakan dari dalam contohnya gempa bumi, banjir, meletusnya gunung berapi, kebakaran hutan yang terjadi karena proses alami musim kemarau. Sedangkan kerusakan dari luar yaitu kerusakan yang disebabkan oleh aktivitas manusia. Bentuk 
kerusakan lingkungan yang disebabkan oleh manusia contohnya pencemaran sungai oleh limbah industri maupun limbah rumah tangga, pencemaran udara yang berasal dari limbah pabrik dan kendaraan bermotor, pencemaran tanah yang disebabkan oleh limbah padat dan zat kimia. Manusia sebagai penguasa lingkungan hidup yang diciptakan Tuhan dengan akal budi tentunya mempunyai peran besar dalam menjaga kelestarian lingkungan serta bertanggung jawab dalam menghindari kerusakan lingkungan. Pemerintah sudah melakukan banyak cara untuk menciptakan lingkungan yang bersih dan sehat bagi seluruh rakyat Indonesia, mulai dari mengeluarkan peraturan larangan membuang sampah di sungai, menyediakan fasilitas pembuangan sampah, penyuluhan bahaya sampah, kampanye cinta lingkungan, dan sebagainya. Upaya-upaya tersebut tentunya membutuhkan adanya kesadaran seluruh masyarakat terhadap kelestarian lingkungannya agar berjalan dengan efektif dan efisien sebagaimana cita-cita pemerintah.

Tahun 2013 Kementerian Lingkungan Hidup dan Kehutanan (KLHK) mengembangkan Indeks Perilaku Peduli Lingkungan (IPPL) yang tertuang dalam kata pengantar laporan survey 2013. Kementerian Lingkungan Hidup dan Kehutanan menyebutkan bahwa perilaku peduli lingkungan maaih perlu dikembangkan. Parameter peduli lingkungan sangat kompleks dapat dilihat dan diukur menggunakan cara tyang sederhana yang merupakan gabungan dari 5 indeks yaitu perilaku membuang sampah, penggunaan listrik, konsumsi barang, pemanfaatan air, dan perilaku terkait emisi karbon. Indeks perilaku peduli lingkungan yang dikembangkan oleh KLHK merupakan hasil survey yang dilakukan diseluruh Indonesia pada tahun 2012. Hasilnya menunjukkan bahwa perilaku peduli lingkungan masih kurang baik, yaitu 0,57 dari total 1. Perilaku peduli lingkungan yang masih kurang baik antara lain tidak memilah sampah (76.1\%), tidak memanfaatkan air bekas cucian sayur/buah/daging/wudhu (75.7\%), membakar sampah (38.2\%), menyalakan lampu di siang hari (24.1\%), limbah air rumah tangga dibuang ke kumpulan air bersih seperti sungai, kolam, rawa, laut (15.8\%), tidak menggunakan lampu hemat energi (15.4\%).(sumber: http://www.neraca.co.id/article/8857 O/indeks-perilaku-peduli-lingkungan diakses pada 16 Desember 2017)

Secara empiris diperoleh bahwa telah banyak pencemaran lingkungan hidup yang terjadi di berbagai negara di seluruh dunia yang bersumber dari kurangnya kepedulian masyarakat terhadap pengelolaan lingkungan hidup. Tidak terkecuali di Kabupaten Sukoharjo Jawa Tengah sudah banyak terjadi pencemaran lingkungan. Mulai dari air sungai, tanah pertanian, dan juga pencemaran udara, contohnya pada Mei 2015 di Sukoharjo terdapat salah satu sungai yaitu sungai Langsur yang tercemar limbah industri sehingga menyebabkan warga sekitar sungai mengalami gatal-gatal. Secara tidak langsung karena air sungai tercemar tanah juga ikut tercemar. Berita terbaru yang dimuat dalam salah satu berita online (sumber:http://industri. 
bisnis.com/read/20180226/257/74324

0/dugaanpencemaran-rayon-utama-

makmur-klhk-tunggu-hasil-

laboratorium diakses pada 16 Maret 2018)

Pada tanggal 26 Februari 2018 pencemaran udara terjadi di Kecamatan Ngunter Kabupaten Sukoharjo dimana udara di daerah tersebut menjadi bau. Berdasarkan data Status Lingkungan Hidup (SLHD) Kabupaten Sukoharjo tahun 2016 sumber pencemar di Kabupaten Sukoharjo terdiri dari 7 sumber pencemar, yaitu jumlah konsumsi Bahan Bakar Minyak (BBM) dan energi total 191.526 kiloliter, Limbah padat rumah sakit total $40 \mathrm{~kg} / \mathrm{hari}$ dan limbah cair rumah sakit total 70m3/hari, timbulan sampah total $2.126,21 \mathrm{~m} 3 /$ hari, limbah padat dan cair dari hotel dan penginapan total $178,16 \mathrm{~m} 3 /$ hari, limbah padat dari lokasi obyek wisata total 1,22 ton/hari, konsumsi bahan bakar untuk keperluan rumah tangga total 695.235 $\mathrm{kg}$, limbah dari industri. Menurut data SIPSN (Sistem Informasi Pengelolaan Sampah Nasional) pada periode 2017 2018 Kabupaten Sukoharjo jumlah sampah yang ditimbun TPA 150.48 ton/hari sedangkan jumlah sampah tidak terkelola 598.00 ton/hari. Sampah tersebut berasal dari timbulan sampah harian ibu kota yaitu 73.79 ton/hari dan timbulan sampah harian non ibu kota yaitu 712.44 ton/hari. Data tersebut menunjukkan perlunya peran serta masyarakat Kabupaten Sukoharjo dalam membantu pemerintah mengatasi permasalahan sampah. Peran serta masyarakat dapat diwujudkan melalui hal-hal kecil seperti tidak membuang sampah sembarangan, mengurangi penggunaan plastik, kertas, kaca dan bahan yang susah terurai lainnya, serta melakukan daur ulang sampah untuk membantu mengurangi volume sampah yang tidak terkelola.

Pemerintah

Kabupaten

Sukoharjo pada tahun 2011 sudah mengeluarkan Peraturan Daerah Nomor 16 tentang Pengelolaan Sampah. Usaha-usaha yang telah dilakukan pemerintah tidaklah cukup apabila tidak dibarengi dengan upaya pencegahan yaitu dengan membentuk karakter kewarganegaraan yang berwawasan lingkungan atau disebut ecological citizenship. Upaya ini ditujukan untuk membentuk masyarakat yang mempunyai pengetahuan dan kepedulian terhadap kelestarian lingkungannya. Kampung Selo yang terletak di Desa Pojok, Kecamatan Tawangsari, Kabupaten Sukoharjo merupakan salah satu wujud menata lingkungan melalui beberapa program yang dirancang untuk meningkatkan kepedulian masyarakat terhadap lingkungan sekitarnya. Kampung Selo Beraksi ini merupakan program yang digagas oleh salah satu pemuda yang bernama Wahyu sapto prasojo yang bertujuan untuk menata lingkungan agar menjadi lebih asri dan berdaya guna. Tujuan akhirnya bukan hanya membuat kampung menjadi bersih dan indah tetapi juga diharapkan dapat memberikan manfaat untuk meningkatkan kesejahteraan masyarakat tanpa merusak lingkungan sekitar.

Gagasan mengenai program Kampung Selo Beraksi awalnya muncul karena melihat kondisi kampung yang kumuh dan kurang tertata dengan baik, sehingga muncul ide untuk membangun desa menjadi lebih bersih dan tertata. Kampung 
Selo dapat dikatakan kumuh karena sebelum adanya program Kampung Selo Beraksi warga sekitar masih membuang sampah sembarangan di sekitar rumah dan di sungai karena letaknya yang dekat dengan sungai Bengawan Solo. Setelah adanya program Kampung Selo Beraksi yaitu bank sampah beraksi warga mau mengumpulkan sampahnya. Dampaknya Kampung Selo Beraksi menjadi semakin bersih bebas dari sampah yang berserakan. Program yang selanjutnya ada di Kampung Selo Beraksi yaitu ada rumah hidroponik, vertical garden, kafe kreatif bambu, dan program-program lainnya. Konsep dari Kampung Selo Beraksi sendiri merupakan desa wisata untuk menarik perhatian masyarakat datang ke Kampung Selo Beraksi untuk bersama-sama belajar banyak hal salah satunya ialah belajar untuk bersama-sama melestarikan lingkungan. Contohnya dalam kegiatan outbound yang mengajarkan untuk membuat kerajinan dari sampah serta belajar menanam pohon sebagai upaya menumbuhkan kepedulian lingkungan terutama pada anakanak.Penulis beranggapan bahwa program Kampung Selo Beraksi yang terletak di Desa Pojok, Kecamatan Tawangsari, Kabupaten Sukoharjo dapat menumbuhkan pengetahuan dan kesadaran masyarakat akan pentingnya menjaga kelestarian lingkungan bagi kehidupan manusia. Tumbuhnya pengetahuan dan kesadaran masyarakat tersebut dapat membentuk karakter kewarganegaraan yang berwawasan lingkungan atau disebut ecological citizenship.

\section{METODE PENELITIAN}

Penelitian kualitatif ini menggunakan pendekatan studi kasus. Penelitian dengan pendekatan studi kasus dimaksudkan agar peneliti dapat mengeksplor pernyataanpernyataan menjadi sebuah pengetahuan. Informasi yang di dapat berasal dari pengamatan, wawancara, dan dokumen-dokumen terkait dengan subjek penelitian. Subjek dalam penelitian ini adalah program Kampung Selo Beraksi yang dapat mengubah perilaku masyarakat sadar akan lingkungan. Objek penelitian adalah masyarakat di Desa Pojok, Kecamatan Tawangsari, Kabupaten Sukoharjo yang merupakan tempat adanya program Kampung Selo Beraksi.

Teknik pengumpulan data dalam penelitian ini yaitu wawancara, observasi, dan analisis dokumen. Wawancara dilakukan dengan beberapa informan, yaitu: 1) pemrakarsa Kampung Selo Beraksi, Wahyu Sapto Prasojo; 2) Ketua karangtaruna Kampung Selo, Muhamad Farhan Yudistira; 3) Anggota karangtaruna Kampung Selo, Defi Pangesti; 4) Direktur bank sampah, Agustina Dyah Indriyani; 5) Perangkat Desa Pojok, Sahono; 6) Warga Kampung Selo, Bayu Adi; 7) Guru SD Islam Terpadu Mutiara Insan Bendosari, Noviyani. Dokumen yang digunakan yaitu UndangUndang Dasar Negara Republik Indonesia Tahun 1945, UndangUndang Nomor 32 Tahun 2009 tentang Perlindungan dan Pengelolaan Lingkungan Hidup, Perda Kabupaten Sukoharjo Nomor 16 Tahun 2011 tentang Pengelolaan Sampah, serta dokumentasi kegiatan di Kampung Selo Beraksi. 
Uji validitas data penelitian ini menggunakan trianggulasi data/sumber dan trianggulasi metode. Adapun data yang peneliti lakukan trianggulasi yaitu hasil wawancara dengan penggerak program Kampung Selo Beraksi, warga sekitar Kampung Selo, pemerintah desa pojok, hasil observasi di Kampung Selo Beraksi dan dokumen terkait profil dan kegiatan yang berkaitan dengan program Kampung Selo Beraksi. Teknik analisis data penelitian antara lain pengumpulan data, reduksi data, penyajian data dan penarikan kesimpulan/verifikasi.

\section{HASIL PENELITIAN DAN PEMBAHASAN}

1. penguatan ecological citizenship dalam mengubah perilaku masyarakat sadar akan lingkungan melalui program Kampung Selo Beraksi di Desa Pojok, Kecamatan Tawangsari, Kabupaten Sukoharjo.

Beberapa kerusakan lingkungan yang terjadi di Indonesia menunjukkan bukti bahwa ada perilaku merusak lingkungan yang dilakukan oleh manusia yaitu pembuangan sampah sembarangan, pembuangan limbah pabrik yang mencemari lingkungan, pembakaran hutan secara liar, penggunaan bahan kimia untuk pertanian, serta pemanfaatan energi secara berlebihan. Terjadinya perilaku merusak lingkungan tersebut karena perkembangan teknologi dan terus bertambahnya populasi manusia sehingga terjadi eksploitasi secara berlebihan tanpa dibarengi dengan tindakan pelestarian lingkungan.

Minimnya kesadaran untuk menjaga kelestarian lingkungan atau krisis ekologi menjadi tanggung jawab warga negara bersama pemerintah untuk meningkatkan perilaku sadar lingkungan. Pembahasan pada hasil penelitian ini menjabarkan analisis yang telah dilakukan peneliti terhadap temuan pada penelitian dengan kajian teori. Berdasarkan analisis paguyuban Kampung Selo melalui program Kampung Selo Beraksi melakukan penguatan perilaku sadar lingkungan yang relevan dengan teori ecological citizenship yaitu tindakan untuk menjaga kelestarian lingkungan. Kegiatan-kegiatan yang ada di Kampung Selo Beraksi sesuai dengan karakteristik kewarganegaraan lingkungan yaitu peduli terhadap lingkungan dengan meningkatkan pengetahuan lingkungan (environmental knowledge), keterampilan lingkungan (environmental skills), sikap lingkungan (environmentalattitudes), partsipasi lingkungan (environmentalparticipation).

Pembahasan dalam penelitian ini dijabarkan ke dalam dua aspek sesuai dengan rumusan masalah dan temuan yang telah disusun yaitu sebagai berikut:

a. Perlunya penguatan ecological citizenship dalam mengubah perilaku masyarakat sadar akan lingkungan melalui program Kampung Selo Beraksi.

Perlunya penguatan ecological citizenship adalah untuk mengubah perilaku masyarakat peduli atau sadar terhadap kebersihan serta kelestarian lingkungan. Perlunya penguatan ini karena peran pemerintah dalam mengubah perilaku masyarakat sadar lingkungan terutama membuang sampah sembarangan melalui 
penyuluhan dan peraturan perundangudangan tidaklah cukup. Diperlukan adanya tindakan secara langsung untuk menggugah kepedulian lingkungan masyarakat melalui kegiatan berwawasan lingkungan. Kampung Selo Beraksi dalam hal ini berupaya meningkatkan kebersihan serta kesehatan lingkungan melalui kegiatan berwawasan lingkungan seperti bank sampah, taman hidroponik, vertical garden, dan galeri kerajinan.

Program Kampung Selo Beraksi merupakan program pro lingkungan yang tepat untuk meningkatkan kesadaran warga terhadap lingkungan. Hal tersebut karena mengubah perilaku masyarakat akan lebih tepat apabila dilakukan melalui pendekatan-pendekatan yang sederhana sehingga mudah dipahami dan diterapkan oleh semua masyarakat. Latar belakang dari adanya program Kampung Selo Beraksi sendiri adalah untuk mengubah kondisi kampung menjadi lebih bersih, sehat, dan tertata, serta untuk menjadikan Kampung Selo sebagai kampung kreatif dan inspiratif yang diharapkan dapat menumbuhkan kemandirian ekonomi warga. Pada tahun 2011 Pemerintah Kabupaten Sukoharjo juga telah mengeluarkan kebijakan berupa Perda No. 16 tahun 2011 tentang Pengelolaan Sampah. Selain mengeluarkan Perda tentang pengelolaan sampah pemerintah juga telah melakukan penyuluhan buang sampah sembarangan di Desa Pojok melalui program pemuda siaga sehat oleh Dinas Kesehatan Sukoharjo.

Penyuluhan serta peraturan yang telah dikeluarkan pemerintah nampaknya masih belum maksimal pengaruhnya terhadap perilaku warga Kampung Selo dalam membuang sampah sembarangan sesuai dengan hasil penelitian yang telah dilakukan. Faktor penyebab kerusakan lingkungan diantaranya kurangnya promosi pemerintah tentang lingkungan, belum optimalnya peran lembaga pendidikan dalam pembelajaran berbasis lingkungan, lemahnya pengawasan dan sanksi terhadap warga yang membuang sampah sembarangan, serta kurangnya kesadaran warga dalam menjadi warga negara ekologis. Program Kampung Selo Beraksi merupakan bentuk pelestarian lingkungan dengan pendekatan dari bawah (bottom-up) diperkuat dengan pendapat Certoma dan Notteboom (2015: 3) bahwa program pelestarian lingkungan oleh pemerintah (topdown) hanya bisa berjalan optimal jika didukung oleh pendekatan dari bawah (bottom-up) dalam bentuk gerakan sosial. Kegiatan bank sampah pada Kampung Selo Beraksi merupakan salah satu bentuk aktivitas melindungi lingkungan sebagaiman yang disampaikan oleh Kymlicka dan Norman dalam Dobson yaitu negara tidak dapat melindungi lingkungan jika warga tidak mau mengurangi, menggunakan kembali, dan mendaur ulang di rumah mereka sendiri.

Peduli lingkungan perlu dikuatkan karena lingkungan sangat berpengaruh terhadap kesejahteraan serta kelangsungan hidup manusia sebagaimana dijelaskan dalam Undang-Undang No. 32 tahun 2009 bahwa lingkungan hidup adalah kesatuan ruang dengan semua benda, daya, keadaan, dan makhluk hidup, termasuk manusia dan perilakunya, yang mempengaruhi alam itu sendiri, 
kelangsungan peri kehidupan, dan kesejahteraan manusia serta makhluk hidup lain. Perilaku peduli lingkungan dilakukan sebagai wujud timbal balik manusia terhadap alam karena telah mencukupi segala kebutuhan manusia yang meliputi sandang, pangan, dan papan, serta oksigen dan air sebagai sumber kehidupan manusia. Selain itu juga sebagai wujud tanggung jawab kita terhadap generasi masa depan dan juga orang lain yaitu mewariskan kelestarian dan kebermanfaatan lingkungan untuk memenuhi hak mereka akan lingkungan yang layak sebagaimana yang kita nikmati saat ini. Sebagaimana disampaikan oleh Dobson bahwa ecological citizenship atau kewarganegaraan ekologis merupakan kewarganegaraan orang asing, dimana tugas kewarganegaraan ekologis adalah milik orang lain sebagai wujud kebajikan (civic virtue). Selain sebagai wujud tanggung jawab warga negara penguatan ecological citizenship perlu dilakukan agar masyarakat melek ekologi sebagai respon dari banyaknya permasalahan lingkungan yang ada.

b. Cara Penguatan ecological citizenship dalam mengubah perilaku masyarakat sadar akan lingkungan melalui program Kampung Selo Beraksi

Penguatan ecological citizenship melalui Kampung Selo Beraksi terwujud dalam Program-program yang berhubungan dengan lingkungan atau pro lingkungan yaitu ada bank sampah, taman hidroponik, vertical garden, galeri kerajinan, outbound. Penguatan merupakan tindakan yang bertujuan untuk memberikan informasi atau umpan balik terhadap suatu tingkah laku sebagai suatu dorongan atau koreksi sehingga meningkatkan kemungkinan berulang kembali tingkah laku tersebut ke arah yang lebih positif. Sebagaimana dijelaskan oleh Hamid Darmadi dalam Fitriani, Abd. Samad, Khaeruddin (2014: 5) bahwa penguatan merupakan segala bentuk respon yang bersifat verbal maupun nonverbal.

Dasar gerakan dari Kampung Selo Beraksi menerapkan konsep 3E yaitu ekologi, edukasi, dan ekonomi diambil dari kata "beraksi" yaitu aktif, kreatif, sehat, dan inspiratif. Penguatan ecological citizenship dalam program Kampung Selo Beraksi diwujudkan melalui pembentukan environmental knowledge, environmental skills, environmental attitudes, environmental participation. Sebagaimana penjelasan Alan R. Berkowitz mengenai kewarganegaraanlingkungan yaitu melibatkanmemberdayakan orang untuk memiliki pengetahuan, keterampilan, dan sikapdiperlukan untuk mengidentifikasi nilai dan tujuan mereka sehubungan dengan lingkungandan bertindak sesuai, berdasarkan pengetahuan terbaik tentang pilihandan konsekuensi. Pertama environmental knowledge yaitu ekspresi berbagai pengalaman dan pengetahuan dalam masalah yang berkaitan dengan lingkungan, dan pemahaman dasar tentang apa yang diperlukan untuk menciptakan dan memelihara lingkungan yang berkelanjutan di antara individu, kelompok, atau organisasi (adapted from UNESCO, 1978). Dapat dilihat dari pengetahuan masyarakat tentang jenis-jenis sampah, cara mendaur 
ulang sampah, dan pengetahuan pentingnya bahan pangan sehat seperti sayuran hidroponik. Kedua environmental skills yaitu kemampuan atau keterampilan yang diperoleh untuk mengidentifikasi, mengantisipasi, mencegah dan menyelesaikan masalah lingkungan, di antara individu, kelompok atau organisasi, (diadaptasi dari UNESCO, 1978). Keterampilan dalam mengatasi problem lingkungan terlihat dari menurunnya aktivitas warga membuang sampah sembarangan di sungai Bengawan Solo dan di pekarangan rumah karena hal tersebut dapat berdampak buruk bagi lingkungan. Selain itu keterampilan untuk melakukan daur ulang juga menjadi salah satu cara untuk meminimalisir permasalahan terkait membludaknya volume sampah di Sukoharjo. Ketiga environmental attitudes yaitu ekspresi serangkaian nilai dan perasaan peduli terhadap lingkungan, dan motivasi untuk berpartisipasi aktif dalam peningkatan dan perlindungan lingkungan, di antara individu, kelompok atau organisasi (diadaptasi dari UNESCO 1978). Motivasi untuk berpartisipasi aktif dalam peningkatan dan perlingkungan lingkungan tercermin dalam kegiatan vertical garden sebagai salah satu upaya penghijauan dan juga outbound dengan menumbuhkan kecintaan terhadap tanaman. Keempat environmental participation yaitu ilustrasi motivasi dan tindakan yang tertanam untuk terlibat aktif di semua tingkatan dalam upaya menciptakan lingkungan yang berkelanjutan, di antara individu, kelompok, atau organisasi (diadaptasi dari UNESCO 1978). Penguatan environmental knowledge, skills, serta attitudes pada akhirnya akan menimbulkan adanya environmental participation tercermin dalam perilaku warga enggan untuk melakukan tindakan pengotoran lingkungan dengan tidak membuang sampah sembarangan, melakukan daur ulang, melakukan penghijauan dengan menanam pohon di rumah, dan mengonsumsi sayuran organik.

Program-program Kampung Selo Beraksi yang telah dijabarkan tersebut merupakan program-program yang dapat mengubah perilaku masyarakat sadar lingkungan dengan pendekatan dari bawah (bottom up). Penguatan ecological citizenship melalui program tersebut diperkuat oleh pendapat Light dalam Maryani (2017: 15) menerima tanggung jawab pribadi dan bertindak sesuai tanggung jawab juga membantu meningkatkan kesadaran warga bahwa perilaku dan sikap mereka bisa membuat perbedaan (Light 2001:28). Pengembangan kewarganegaraan ekologi melalui pendekatan dari bawah (bottom up) yaitu melalui peran masyarakat mempunyai peran yang penting, sebagaimana hasil penelitian yang dilakukan oleh Budimansyah dan Prasetiyo yang meneliti tentang Komunitas Bandung Berkebun melalui program-program pro lingkungan seperti urban farming, school urban farming, street urban farming, dan campus urban farmingterbukti mengembangkan komitmen, kepercayaan diri, dan kompetensi warga negara yang bermuara kepada kebajikan kewarganegaraan (civic virtue) yang diaktualisasikan lewat serangkaian upaya menjaga kelestarian ekologi. Kegiatan pro lingkungan sebagai ciri kewarganegaraan lingkungan yang 
diperkuat oleh Ashley (2000: 131) yang menyebutkan bahwa pro lingkungan menjadi ciri kewarganegaraan lingkungan. Ecological citizenship dalam kaitannya dengan teori kewarganegaraan relevan dengan teori kewarganegaraan republikan yang disampaikan oleh Dagger dalam Handbook of Citizenship Studies (2002: 147-149) bahwa kewarganegaraan republikan memerlukan komitmen terhadap kebaikan bersama (common good) dan partisipasi aktif dalam urusan publik. Berbicara mengenai lingkungan melestarikan lingkungan harus dilakukan bersama-sama sebagai wujud tanggungjawab terhadap kebaikan bersama (common good).

\section{Hambatan yang dihadapi dalam} mewujudkan program Kampung Selo Beraksi di Desa Pojok, Kecamatan Tawangsari, Kabupaten Sukoharjo

Hambatan adalah sesuatu yang dapat melemahkan dan menghalangi berjalannya suatu program yang terbagi dalam hambatan internal dan eksternal. Hambatan internal dalam penelitian ini merupakan hambatan yang berasal dari paguyuban selo beraksi yang merupakan pelaku utama adanya program Kampung Selo Beraksi. Hambatan internal pelaksanaan program Kampung Selo Beraksi adalah keterbatasan sumber daya manusia dan keterbatasan sumber dana. Keterbatasan sumber daya manusia terjadi karena terdapat beberapa anggota paguyuban Kampung Selo yang kurang aktif dalam menjalankan program Kampung Selo Beraksi. Adanya anggota yang kurang aktif berpengaruh terhadap kemaksimalan program seperti contohnya dalam menyelesaikan suatu project atau kegiatan membutuhkan waktu yang lama karena kekurangan orang. Belum maksimalnya keaktifan serta partisipasi anggota paguyuban dikarenakan alasan kesibukan seperti bekerja, sekolah, dan kepertingan lainnya. Keterbatasan sumber dana menjadi penghambat terutama dalam pengembangan program Kampung Selo Beraksi. Hal ini terjadi karena sumber dana untuk program Kampung Selo Beraksi berasal dari swadaya masyarakat dan donasi dari pihak luar. Swadaya masyarakat sendiri sifatnya sukarela agar tidak membebani anggota paguyuban sehingga sangat minim dana yang ada.

Hambatan eksternal dari program Kampung Selo Beraksi yaitu berasal dari respon dan partisipasi warga dan pemerintah, serta letak geografis Kampung Selo Beraksi. Hambatan yang datang dari masyarakat lebih banyak mengenai adanya sikap kontra dari beberapa warga terhadap program-program yang ada. Sikap kontra ini muncul karena kurangnya pemahaman warga terhadap program tersebut meliputi bagaimana cara membuat dan menjalankannya serta manfaatnya untuk warga. Tidak jarang sikap warga yang kurang setuju dengan apa yang kita lakukan itu memunculkan komentar-komentar negatif. Hambatan yang datang dari pemerintah yaitu masih kurangnya partisipasi pemerintah desa setempat. Walaupun pemerintah desa setempat mendukung adanya program desa wisata namun untuk aksi nyata yang ditunjukan pemerintah sampai 
sekarang ini belum begitu banyak. Bantuan dana dari pemerintah desa setempat dalam pembangunan program Kampung Selo Beraksi sejauh ini belum ada karena baru akan dianggarkan pada tahun 2019. Hambatan dari lingkungan ini lebih karena letak Kampung Selo Beraksi yang cukup jauh dari kota sehingga membuat Kampung Selo Beraksi kurang dikenal dan mendapatkan perhatian dari pihak luar. Selain itu belum maksimalnya penataan kampung karena keterbatasan tempat untuk menjalankan program Kampung Selo Beraksi.

\section{SIMPULAN DAN SARAN Simpulan}

Berdasarkan hasil penelitian dan pembahasan, maka dapat ditarik kesimpulan sebagai berikut:

1. Perlunya dilakukan penguatan ecological citizenship untuk mengubah perilaku masyarakat lebih sadar lingkungan dikarenakan semakin banyak permasalahan lingkungan karena ulah manusia yang kurang bertanggungjawab terhadap lingkungan. Peran pemerintah melalui penyuluhan dan sosialisasi serta peran persekolahan dalam pembelajaran berbasis lingkungan dirasa belum optimal sehingga masih terjadi perilaku masyarakat melakukan pengerusakan lingkungan seperti membuang sampah dan limbah pabrik di sungai,pembakaran hutan secara liar, penggunaan bahan kimia untuk pertanian, serta pemanfaatan energi secara berlebihan. Perlu adanya pendekatan dari bawah (bottom up) yaitu tindakan kolektif yang mengajak masyarakat secara langsung melakukan kegiatankegiatan berwawasan lingkungan. Salah satunya program Kampung Selo Beraksi yang meggalakan program pro lingkungan sebagai sarana pembentukan kewarganegaraan ekologis melalui masyarakat.

2. Cara Penguatan ecological citizenship dalam mengubah perilaku masyarakat sadar akan lingkungan melalui program Kampung Selo Beraksi lebih menekankan pada tindakan penguatan secara non verbal yang diwujudkan dalam kegiatankegiatan yaitu bank sampah, taman hidroponik, vertical garden, galeri kerajinan, outbound. Kegiatan bank sampah dilakukan untuk mengajak warga tidak membuang sampah sembarangan sekaligus melatih keterampilan warga dalam memilah sampah. Kegiatan taman hidroponik dilakukan untuk memberi pengetahuan dan mengajak warga bagaimana menanam yang lebih ramah lingkungan. Kegiatan vertical garden dijadikan sarana untuk memotivasi warga lebih mencintai tanaman. Kegiatan galeri kerajinan sebagai sarana memotivasi warga untuk terus berkreasi terutama membuat kerajinan dari sampah. Kegiatan outbounddilakukan sebagai sarana menumbuhkan perilaku peduli lingkungan melalui permainanpermainan yang melibatkan peserta sehingga mempunyai keterampilan seperti membuat kerajinan dari sampah dan menanam pohon.Penguatan 
ecological citizenship dalam program Kampung Selo Beraksi diwujudkan melalui pembentukan environmental knowledge, environmental

skills, environmental

attitudes, environmental participation.

3. Hambatan yang dihadapi dalam melaksanakan program Kampung Selo Beraksi terbagi menjadi dua yaitu hambatan internal dan hambatan eksternal. Pertama hambatan internal pelaksanaan program Kampung Selo Beraksi terdapat dua hambatan yaitu keterbatasan sumber daya manusia dan keterbatasan sumber dana. Keterbatasan sumber daya manusia lebih mengarah kepada partisipasi anggota paguyuban sebagai penggerak adanya program Kampung Selo Beraksi dimana terdapat beberapa anggota yang kurang aktif. Keterbatasan sumber dana terjadi karena dana yang diperoleh hanya dari swadaya sukarela anggota paguyuban sehingga masih sangat minim. Kedua hambatan eksternal program Kampung Selo Beraksi yaitu hambatan dari masyarakat, pemerintah, dan lingkungan. Hambatan dari masyarakat yaitu kurangnya partisipasi masyarakat secara aktif dalam pelaksanaan kegiatan dan adanya sikap kontra dari beberapa masyarakat terhadap program Kampung Selo Beraksi. Hambatan dari pemerintah yaitu masih kurangnya perhatian dan partisipasi pemerintah desa dalam menjalankan dan mengembangkan program Kampung Selo Beraksi.

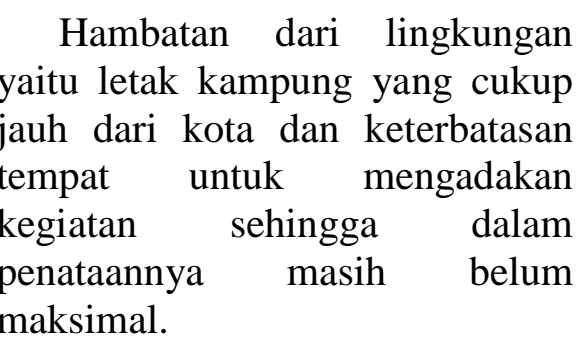

\section{Saran}

Berdasarkan kesimpulan dari penelitian ini, terdapat saran yang ingin peneliti berikan. Adapun saran yang diberikan antara lain:

1. Kepada paguyuban Kampung Selo agar lebih meningkatkan kreatifitas serta partisipasinya dalam mewujudkan programprogram peduli lingkungan. Kepada anggota paguyuban agar lebih ditingkatkan lagi keaktifannya dalam program Kampung Selo Beraksi.

2. Kepada masyarakat Desa Pojok agar lebih ditingkatkan kepeduliannya terhadap lingkungan serta partisipasinya terhadap kegiatan-kegiatan pelestarian lingkungan.

Kepada pemerintah Desa Pojok agar lebih memperhatikan dan mendukung program-program yang bermanfaat bagi masyarakat dan lingkungan. Perlu peningkatan koordinasi dengan masyarakat setempat dalam menyusun programprogram pembangunan desa. 


\section{DAFTAR PUSTAKA}

Alan R. Berkowitz dkk. 2004. A framework for integrating ecological literacy, civics literacy, and environmental citizenship in environmental education. Jurnal Internasional, 227-266/40.

Ashley, M. (2000) 'Behaviour Change and Environmental Citizenship: a case for spiritual development?', International Journal of Children's Spirituality, 5 (2): 131-45.

Certoma, C., dan Notteboom, B. 2015. Informal planning in a transactive governmentality: Re-reading planning practices through Ghent's community gardens. Planning Theory:1-24.

Dobson, A. Tanpa Tahun. Ecological citizenship: A disruptive influence?, (Online), (http://www.vedegylet.hu/okopolitika/Dobson\%20\%20Ecological\%20Citizenship.pdf, diakses 25 September 2015).

Dobson, Andrew. 2003. Citizenship and the Environment. Oxford: Oxford University Press.

F. Isin, Engin \& Bryan S. Turner. 2002. Handbook Of Citizenship. New Delhi: SAGE Publications.

Fitriani dkk. 2014. Penerapan Teknik Pemberian Reinforcement (Penguatan) Untuk Meningkatkan Hasil Belajar Fisika Pada Peserta Didik Kelas VIII.A SMP PGRI Bajeng Kabupaten Gowa. Jurnal nasional, Vol. 2. Hlm. 196.

Temuat dalam: https://media.neliti.com/media/publications/120887-IDpenerapan-teknik-pemberian-reinforcement.pdf yang diakses pada 24 April 2018 pukul : 10.00 WIB.

Informasi Pengelolaan Sampah Kabupaten Sukoharjo Tahun 2018. Diperoleh pada 10 Oktober 2018 dari http://sipsn.menlhk.go.id/

Informasi Volume Sampah di Indonesia Tahun 2018. Diperoleh pada 13 Januari 2018

dari

https://www.idntimes.com/news/indonesia/indianamalia/volume-sampah-

2018-diprediksi-mencapai-665-juta-ton-1/full

Light, Andrew. 2001. The urban blind spot in environmental ethics. Environmental Politics 10 (1), 7-35.

Maryani. 2017. Strategi Pembentukan Kewarganegaraan Ekologis. Prosiding Konferensi Nasional Kewarganegaraan III, Universitas Ahmad Dahlan Yogyakarta: 11 November 2017. 10-17.

Muhaimin. 2015. Membangun Kecerdasan Ekologis Model Pendidikan Untuk Meningkatkan Kompetensi Ekologis. Bandung: Alfabeta.

Peraturan Daerah Kabupaten Sukoharjo Nomor 16 Tahun 2011 Tentang Pengelolaan Sampah. Diperoleh pada 3 Desember 2018 dari 
http://ciptakarya.pu.go.id/plp/upload/peraturan/Perda_Sampah_Kab_Suko harjo_No_16_Th_2011.pdf

Undang-Undang Dasar 1945.

Undang-Undang Nomor 39 Tahun 1999 tentang Hak Asasi Manusia. Diperoleh $\begin{array}{llll}\text { pada } & 4 & \text { Januari } & 2018\end{array}$ https://www.ilo.org/dyn/natlex/docs/ELECTRONIC/55808/.../IDN55808\% 20IDN.pdf

Undang-Undang Nomor 32 Tahun 2009 Tentang Perlindungan dan Pengelolaan Lingkungan Hidup. Diperoleh pada 4 Januari 2018 dari http://jdih.menlh.go.id/pdf/ind/INDPUU12009UU\%20No.\%2032\%20Th\% 202009_Combine.pdf

Tim Ilngold. 2000. The Perception of the Environmental. USA: Taylor \& Francis e-Library. 